\title{
Sustained function of alginate-encapsulated human islet cell implants in the peritoneal cavity of mice leading to a pilot study in a type 1 diabetic patient
}

\author{
D. Jacobs-Tulleneers-Thevissen • M. Chintinne • \\ Z. Ling • P. Gillard $\cdot$ L. Schoonjans $\cdot$ G. Delvaux • \\ B. L. Strand • F. Gorus - B. Keymeulen • D. Pipeleers • \\ on behalf of the Beta Cell Therapy Consortium EU-FP7
}

Received: 8 January 2013 / Accepted: 14 March 2013 / Published online: 26 April 2013

(C) Springer-Verlag Berlin Heidelberg 2013

\begin{abstract}
Aims/hypothesis Alginate-encapsulated human islet cell grafts have not been able to correct diabetes in humans, whereas free grafts have. This study examined in immunodeficient mice whether alginate-encapsulated graft function was inferior to that of free grafts of the same size and composition. Methods Cultured human islet cells were equally distributed over free and alginate-encapsulated grafts before implantation in, respectively, the kidney capsule and the peritoneal cavity of non-obese diabetic mice with severe combined immunodeficiency and alloxan-induced diabetes. Implants were followed for in vivo function and retrieved for analysis
\end{abstract}

D. Jacobs-Tulleneers-Thevissen $\cdot M$. Chintinne $\cdot$ Z. Ling $\cdot$

P. Gillard • G. Delvaux • F. Gorus • B. Keymeulen •

D. Pipeleers $(\square)$

Diabetes Research Center, Brussels Free University,

Laarbeeklaan 103,

1090 Brussels, Belgium

e-mail: Daniel.Pipeleers@vub.ac.be

D. Jacobs-Tulleneers-Thevissen $\cdot M$. Chintinne $\cdot$ Z. Ling $\cdot$

G. Delvaux $\cdot$ F. Gorus $\cdot$ B. Keymeulen $\cdot$ D. Pipeleers

Universitair Ziekenhuis Brussel, Brussels, Belgium

P. Gillard

Department of Pathophysiology and Endocrinology,

Catholic University of Leuven, Louvain, Belgium

L. Schoonjans

Beta-Cell NV, Brussels, Belgium

B. L. Strand

Department of Biotechnology, Norwegian University of Science

and Technology, Trondheim, Norway of cellular composition (all) and insulin secretory responsiveness (capsules).

Results Free implants with low beta cell purity $(19 \pm 1 \%)$ were non-functional and underwent $90 \%$ beta cell loss. At medium purity $(50 \pm 1 \%)$, they were functional at post-transplant week 1 , evolving to normoglycaemia (4/8) or to C-peptide negativity (4/8) depending on the degree of beta cell-specific losses. Encapsulated implants immediately and sustainably corrected diabetes, irrespective of beta cell purity (16/16). Most capsules were retrievable as single units, enriched in endocrine cells that exhibited rapid secretory responses to glucose and glucagon. Single capsules with similar properties were also retrieved from a type 1 diabetic recipient at post-transplant month 3 . However, the vast majority were clustered and contained debris, explaining the poor rise in plasma C-peptide.

Conclusions/interpretation In immunodeficient mice, i.p. implanted alginate-encapsulated human islet cells exhibited a better outcome than free implants under the kidney capsule. They did not show primary non-function at low beta cell purity and avoided beta cell-specific losses by rapidly establishing normoglycaemia. Retrieved capsules presented secretory responses to glucose, which was also observed in a type 1 diabetic recipient.

Trial registration: ClinicalTrials.gov NCT01379729

Funding: This study was supported by grants from the JDRF (centre grant 4-2005-1327), the Research Foundation Flanders (G.0801.10), the 6th and 7th Framework Program of the European Commission (numbers 512145 and 241883), and the Agency for Innovation by Science and Technology in Flanders (IWT-TBM7 090884).

Keywords Cell therapy · Encapsulation · Islet transplantation 


\section{Abbreviations}

BW Body weight

CK Creatinine kinase

NOD/SCID Non-obese diabetic/severe combined immunodeficiency

\section{Introduction}

Intraportal islet cell transplantation can correct hyperglycaemia in type 1 diabetic patients, but most recipients exhibit a progressive reduction in implant function over the subsequent 5 years [1]. This decline might be attributed to various causes including inflammatory and immune responses to the donor tissue [2-4]. In order to protect grafts against this reactivity, encapsulation methods have been developed for implants in extra-hepatic sites [5,6]. Alginate microcapsules have been the longest in use and technical advances have been made in improving their biocompatibility, stability and permeability, and in producing variants with selected properties [7-9]. They have allowed successful allotransplants of islet tissue in the peritoneal cavity of rodents [10-12] and of large animals $[13,14]$, often without the need for continuous immune suppression [11-14].

Clinical studies with alginate-encapsulated human islet cells have not yet reproduced these promising data in man [15-17]. In the small series undertaken so far in type 1 diabetic recipients it is unclear whether the poor outcome was caused by an initially insufficient beta cell mass or by compromised survival of implants in the peritoneal cavity. Outcome of human islet cell implants can differ with their site, and is probably influenced by variability in their cellular composition whereby a large proportion of nonendocrine cells might interfere with function [18].

In the present study we compared the metabolic outcome of free and alginate-encapsulated human beta cell preparations with the same cellular composition following implantation in, respectively, the kidney subcapsular space and the peritoneal cavity of diabetic immunodeficient mice. Alginateencapsulated implants exhibited a better metabolic effect and appeared to be composed of beta cells with potent glucose responsiveness. These data led us to a pilot study in a type 1 diabetic patient to examine whether functional beta cells could also be retrieved from the peritoneum 3 months after injection of an alginate-encapsulated human islet cell graft.

\section{Methods}

Preparation of free and alginate-encapsulated human beta cell grafts for transplantation in diabetic NOD/SCID mice Cultured human beta cell preparations were provided by our beta cell bank, which receives donor organs from the Eurotransplant International Foundation (Leiden, the Netherlands). Isolates that could not be used for clinical transplantation were made available according to Eurotransplant guidelines and under approval of our institutional ethics committee. Six preparations were used for transplantation in mice. After 3-15 days' culture, they were characterised for their cellular composition including beta cell number, purity and insulin content [19]. The available human cell isolates were combined and divided over preparations for free and alginateencapsulated grafts aiming at injection of $2 \times 10^{6}$ beta cells per mouse. For encapsulation, $15 \times 10^{6}$ to $20 \times 10^{6}$ cells $/ \mathrm{ml}$ were suspended in $1.8 \%$ ultrapure alginate $(68 \%$ glucuronic acid, $32 \%$ mannuronic acid; Pronova UP-LVG [Nova Matrix, Sandvika, Norway]; $0.3 \mathrm{~mol} / 1 \mathrm{mannitol}$ [Sigma-Aldrich, Steinheim, Germany]; pH 7.2-7.4) before generation of micro-droplets in barium-calcium solution $(50 \mathrm{mmol} / \mathrm{l} \mathrm{calci-}$ um chloride and $1 \mathrm{mmol} / \mathrm{l}$ barium chloride in $10 \mathrm{mmol} / \mathrm{l}$ MOPS [J. T. Baker, Deventer, the Netherlands]; $0.15 \mathrm{~mol} / \mathrm{l}$ mannitol and $0.05 \%$ Tween-20 [Merck, Darmstadt, Germany]; $\mathrm{pH}$ 7.2-7.4) [9]. Free and alginate-embedded preparations were cultured overnight before transplantation in 7- to 9week-old male non-obese diabetic/severe combined immuno-

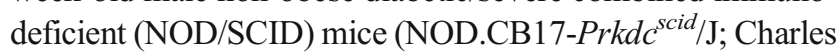
River, L'Arbresle, France). Diabetes was induced by tail vein injection of alloxan $(50 \mathrm{mg} / \mathrm{kg}$; Sigma-Aldrich) $36 \mathrm{~h}$ before transplantation under general anaesthesia (ketamine/xylazine). At transplantation, all animals had glycaemia $>25 \mathrm{mmol} / \mathrm{l}$. Each free graft was divided into two fractions of similar size for insertion in the left and right renal subcapsular space [20]; the alginate-encapsulated equivalent was injected i.p. A sample was taken from each graft for pre-transplant analysis. The 'Principles of laboratory animal care' were followed, as well as specific national laws where applicable. The clinical graft was prepared from four donors and alginate-encapsulated using the same procedure.

Function of human beta cell implants The term 'graft' is used for cell preparations before implantation, and 'implant' for the tissue after injection. Function of implants was assessed through plasma human C-peptide levels and blood glucose concentrations. Human C-peptide was measured by time-resolved fluorescence immunoassay [21] with a lower detection limit of $0.03 \mathrm{nmol} / 1$ [22]; a minimum level of $0.17 \mathrm{nmol} / 1$ was set as the criterion for a functioning implant [23]. A $2 \mathrm{~h}$ fasting morning glycaemia $<8.5 \mathrm{mmol} / \mathrm{l}$ was taken as an index of metabolic correction, being $>20 \mathrm{mmol} / \mathrm{l}$ in all diabetic controls. Since the pancreatic insulin content of all alloxan-treated animals was under $5 \%$ of values in non-diabetic controls, glycaemic correction was attributed to a metabolically adequate implant.

Cellular composition of human beta cell implants Implants were harvested at post-transplant week 5. Retrieved 
capsules were counted and processed for immunocytochemistry and insulin assay [24]. In recipients of free grafts, the right kidney was snap-frozen in liquid nitrogen and stored at $-80^{\circ} \mathrm{C}$ until extraction in acetic acid for the insulin assay [24]. The left kidney was fixed in 4\% (wt/vol.) phosphatebuffered formalin, embedded in paraffin and serially sectioned for histological (haematoxylin-eosin-saffron staining) and immunohistochemical analysis. Cell types were identified by rabbit anti-glucagon $(1: 1,000$ to $1: 5,000)$, guinea pig anti-insulin $(1: 1,000$ to $1: 10,000)$ (both antibodies raised by C. van Schravendijk at our centre), rabbit anti-synaptophysin (1:5,000; Acris, Herford, Germany) for endocrine cells, and mouse anti-creatinine kinase (CK)19 (1:20; Dako, Glostrup, Denmark) for duct cells. The endocrine and duct cell masses were determined as cell volumes according to Cavalieri's principle. Sections sampled throughout the graft were stained and photographed on the Pathway BioImager 855 or 435 for determining positive surface areas (IP Lab software; BD Biosciences, San Jose, CA, USA), which, together with the distance between sections, allowed calculation of total cell masses [25]. In recipients of encapsulated grafts, capsules were retrieved by peritoneal lavage and examined under a stereomicroscope for integrity and adherence of fibrosis and cells. Selected numbers were taken for electron microscopy and immunocytochemical analysis (fixation in $2.5 \%$ [wt/vol.] glutaraldehyde) [26] and for overnight culture before perifusion at different glucose concentrations [27, 28]. Dead cells were identified by ruptured plasma membranes. Their percentage was determined in free and encapsulated preparations at the time of transplantation and explantation.

Transplantation of an alginate-encapsulated human beta cell graft in a type 1 diabetic patient An alginateencapsulated human beta cell preparation was injected i.p. into a 61-year-old female type 1 diabetic patient $(68 \mathrm{~kg}$ body weight $[\mathrm{BW}]$ ) who was under immune-suppressive therapy for an intraportal islet cell graft that she had received 5 years earlier. For 9 months, her plasma C-peptide levels had been 0.03-0.07 nmol/1, which was under the $0.17 \mathrm{nmol} / 1$ limit that was set for a functional intraportal implant [23]. She had been informed that the present protocol was intended for patients with a failing islet cell graft but still on immune therapy, and consented to participate in the study.

The protocol was approved by the institutional ethics committee and registered on ClinicalTrials.gov (NCT01379729). The encapsulation procedure was conducted in our beta cell bank, which is accredited for preparing clinical grafts. The graft, containing $2.4 \times 10^{6}$ beta cells $/ \mathrm{kg} \mathrm{BW}$ (approximately 300,000 islet equivalent [19]), was injected in the peritoneal cavity through laparoscopy under general anaesthesia. Immune therapy consisted of basiliximab $(20 \mathrm{mg}$ i.v. on day of transplantation and post-transplant day 4) and continued maintenance dosages of tacrolimus (trough levels 8-10 ng/ml) and mycophenolate mofetil (1.5 g/day). At post-transplant month 3 , a second laparoscopy was performed to inspect the peritoneal cavity for adhesions and for retrieval of implanted capsules. Free-floating capsules were obtained by peritoneal lavage and processed as described. Capsules that adhered to the peritoneum were biopsied with surrounding tissue and processed for light microscopic analysis.

Statistical analysis Results are expressed as means \pm SEM. Statistical analysis was carried out using Prism 5 (GraphPad Software, San Diego, CA, USA). Differences between experimental groups were calculated by unpaired two-tailed $t$ test or paired two-tailed $t$ test when appropriate. Comparison of multiple groups was performed by one-way ANOVA using Tukey's post hoc test.

\section{Results}

Comparison of metabolic effect of free and alginateencapsulated human beta cell implants We compared the metabolic effect of free and alginate-encapsulated human beta cell grafts with similar composition (Tables 1 and 2), following implantation in, respectively, the renal subcapsular space and the peritoneal cavity.

Free grafts reduced glycaemia on post-transplant day 1, but all 12 recipients were again hyperglycaemic at posttransplant week $1(>20 \mathrm{mmol} / \mathrm{l})$, four being non-functional (plasma human C-peptide $<0.17 \mathrm{nmol} / 1$ ) and eight presenting an average level of $0.93 \pm 0.09 \mathrm{nmol} / \mathrm{l}$ (Table 1 ). The subgroup with non-functional grafts had received the same number of beta cells as the eight that were C-peptidepositive, but at lower purity and with a lower cellular insulin content (Table 1); they remained non-functional during follow-up. Of the eight with function at post-transplant week 1, four progressed to normoglycaemia during the subsequent 3 weeks, with progressively increasing human C-peptide levels; the four others remained hyperglycaemic with declining C-peptide levels (Fig. 1).

Alginate-encapsulated grafts resulted in functional implants and normoglycaemia in 16/16 recipients from posttransplant week 1 until the end of the study (Table 2, Fig. 1). Four had received a graft with similar composition to that in free grafts which resulted in non-function.

Correlation between metabolic outcome of free human beta cell grafts and composition and functional state of implants at post-transplant week 5 Free implants were classified according to their metabolic outcome, i.e. primary nonfunction from post-transplant week $1(n=4)$, transient function with sustained hyperglycaemia $(n=4)$, and metabolic correction (sustained function and normoglycaemia, $n=4$ ). 
Table 1 Influence of graft composition on primary (non-) function of human islet cell implants in diabetic NOD/SCID mice

\begin{tabular}{|c|c|c|c|c|}
\hline \multirow{2}{*}{$\begin{array}{l}\text { Variable } \\
\text { Plasma human C-peptide at post-transplant week } 1(\mathrm{nmol} / \mathrm{l}) \\
n\end{array}$} & \multicolumn{3}{|l|}{ Free graft } & \multirow{2}{*}{$\begin{array}{l}\text { Encapsulated graft } \\
>0.17 \\
16 / 16\end{array}$} \\
\hline & $\begin{array}{l}0.03-0.16 \\
4 / 12\end{array}$ & $\begin{array}{l}0.6-1.56 \\
8 / 12\end{array}$ & $\begin{array}{l}0.03-1.56 \\
12 / 12\end{array}$ & \\
\hline \multicolumn{5}{|l|}{ Cellular composition } \\
\hline Beta cells $(\%)$ & $19 \pm 1$ & $50 \pm 1^{* *}$ & $39 \pm 4$ & $42 \pm 4$ \\
\hline Alpha cells (\%) & $4 \pm 1$ & $14 \pm 1^{* *}$ & $11 \pm 2$ & $12 \pm 1$ \\
\hline Duct cells $(\%)$ & $68 \pm 1$ & $33 \pm 2^{* *}$ & $45 \pm 5$ & $41 \pm 4$ \\
\hline \multicolumn{5}{|l|}{ Beta cells } \\
\hline Number $\left(\times 10^{6} / \mathrm{kg} \mathrm{BW}\right)$ & $82 \pm 4$ & $82 \pm 4$ & $82 \pm 3$ & $95 \pm 6$ \\
\hline Insulin content ( $\mu \mathrm{g} / \mathrm{graft})$ & $20.8 \pm 0.6$ & $41.4 \pm 5.6^{*}$ & $34.6 \pm 4.8$ & $33.8 \pm 3.4$ \\
\hline
\end{tabular}

Data represent means \pm SEM

Statistical analysis of differences between subgroups of free grafts was calculated using one-way ANOVA with Tukey's post hoc test ${ }^{*} p<0.05,{ }^{*} p<0.001$ (there was no difference in respective percentages of dead cells: $<10 \%$ in all [sub]groups)

Their respective composition at post-transplant week 5 was compared with each other as well as with that of the endocrine pancreas in normal mice. In each of the three subgroups, implants presented clusters of endocrine cells between ductlike structures that were lined with CK19-positive cells. There was virtually no inflammation. There was no difference in their respective CK19-positive duct cell mass (measured as volume; Table 3). In the primary non-function subgroup, the mass was comparable with the endocrine cell mass (insulinand glucagon-positive volumes). This subgroup had received grafts with a significantly higher proportion of duct cells $(68 \%$ vs $33 \%$ in the two others; $p<0.001$ ). The subgroups with transient function and with metabolic correction contained, respectively, a five- and tenfold higher beta cell mass, whereas their alpha cell mass was only 2.5 -fold higher. The differences in metabolic outcome at post-transplant week 5 are thus correlated to the beta cell mass at this time point.

When expressing beta cell mass in the implants as a percentage of that in the normal adult mouse pancreas, it represented $6 \%$ in the primary non-function group, $33 \%$ in the transient function group and $64 \%$ in the metabolic correction group (Table 3). Since each subgroup had received a similar number of beta cells, it is concluded that the two hyperglycaemic groups lost, respectively, ten- and twofold more donor beta cells compared with the normoglycaemic group. Such a loss was not seen for the alpha cells, which represented $50 \%$ in the primary nonfunction group and at least $100 \%$ in the two other groups.

The insulin content of implants (Table 3) in the subgroups with primary non-function $(1 \mu \mathrm{g})$ or transient function $(2.7 \mu \mathrm{g})$ was 15 - to 20 -fold lower than that in their initial grafts $(20-40 \mu \mathrm{g}$; Table 1). This decline resulted in part from a loss of beta cells, as indicated by a comparison of their beta cell mass with that of the corresponding duct cell mass and that in the subgroup with metabolic correction (Table 3). In addition, the remaining cells degranulated as derived from the insulin content per beta cell volume and as expected after prolonged hyperglycaemia. The insulin content of transiently functioning implants corresponded to $9 \%$ of that in the normal mouse pancreas but was $60 \%$ in implants with sustained metabolic correction (Table 3). Since the latter $(17.9 \mu \mathrm{g})$ was also $50 \%$ lower than in the initial grafts $(34.6 \mu \mathrm{g}$; Table 1$)$, it may be concluded that a substantial beta cell loss also occurred in this subgroup.

Correlation between metabolic outcome of alginateencapsulated human beta cell grafts and composition and functional state of implants at post-transplant week 5 At post-transplant week 5 , most alginate capsules were free floating in the abdomen. They were retrieved by peritoneal

Table 2 Metabolic outcome of free and alginate-encapsulated human islet cell implants in diabetic NOD/SCID mice

\begin{tabular}{|c|c|c|c|c|c|c|c|c|}
\hline \multirow[t]{3}{*}{ Graft } & \multicolumn{4}{|c|}{ No. of recipients with plasma human C-peptide $>0.17 \mathrm{nmol} / 1$} & \multicolumn{4}{|c|}{ No. of recipients with blood glucose $<8.5 \mathrm{mmol} / \mathrm{l}$} \\
\hline & \multicolumn{4}{|c|}{ Post-transplant week } & \multicolumn{4}{|c|}{ Post-transplant week } \\
\hline & 1 & 5 & 20 & 30 & 1 & 5 & 20 & 30 \\
\hline Free & $8 / 12$ & $4 / 12$ & - & - & $0 / 12$ & $4 / 12$ & - & - \\
\hline Encapsulated & $16 / 16$ & $16 / 16$ & $6 / 6$ & $3 / 3$ & $12 / 16$ & $16 / 16$ & $6 / 6$ & $3 / 3$ \\
\hline
\end{tabular}


Fig. 1 Blood glucose (a, b) and plasma human C-peptide (c, d) levels expressed as mean $\pm \mathrm{SEM}$. (a, c) Recipients of free graft under kidney capsule: white triangles, subgroup with persistent C-peptide $<0.17 \mathrm{nmol} / 1$ (primary non-function, $n=4$ ); white circles, subgroup with persistent hyperglycaemia and progressively decreasing plasma $\mathrm{C}$-peptide levels (transient function, $n=4$ ); black circles, subgroup with normalisation of glycaemia (metabolic correction, $n=4)$. (b, d) Recipients of encapsulated graft $(n=16)$ in peritoneal cavity. Recipients of all subgroups are compared with kidney capsulemetabolic correction recipients. One-way ANOVA with Tukey's post hoc test: ${ }^{*} p<0.05, * * p<0.01$, $* * * p<0.001$
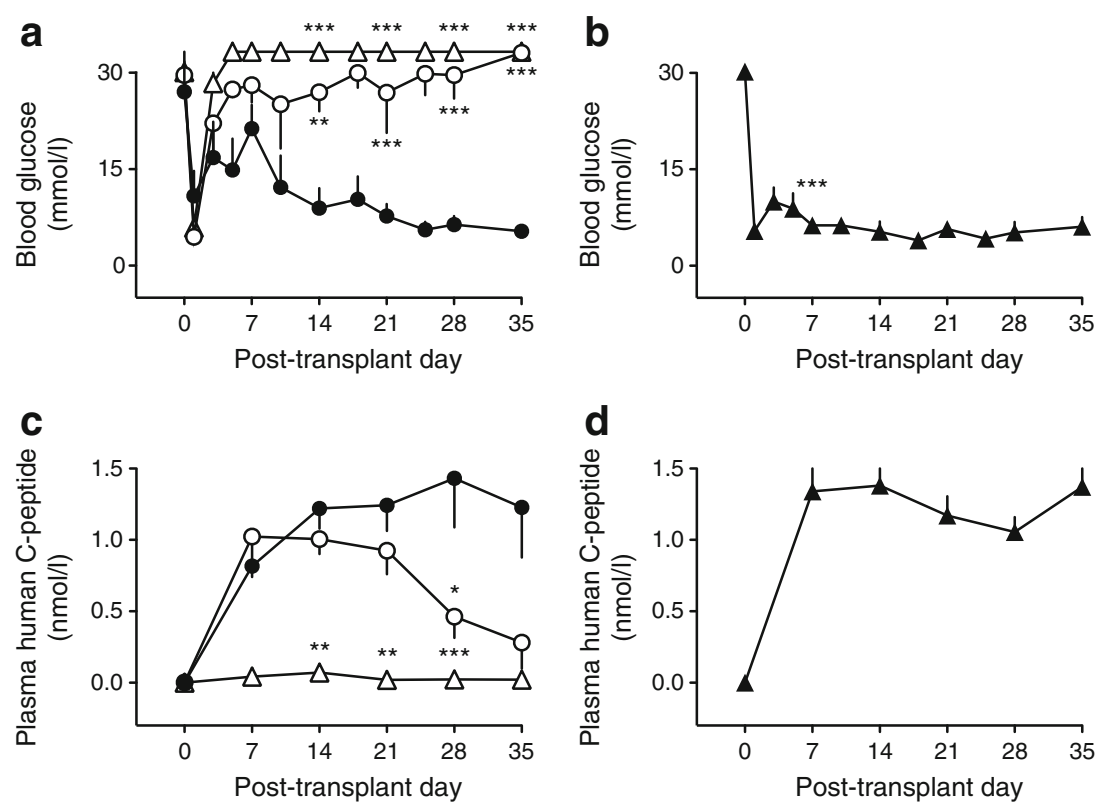

lavage and examined for their structure, cellular composition and functional properties. The capsules showed no fibrosis or cellular overgrowth; more than 95\% were intact and round-shaped (Fig. 2a,b). They contained mostly living cells (15\% dead cells), the majority in the form of endocrine cell clusters with well-granulated cells and intact ultrastructure, the minority in the form of non-granulated cells (Fig. 2c,d). The percentages of beta and alpha cells were significantly higher than those in the initial graft (Table 4), and thus also the percentage of endocrine cells.
Encapsulated implants were examined for their glucose-inducible insulin release following overnight culture. Capsules were loaded on a perifusion column and exposed to four different glucose concentrations with and without glucagon [27, 28]. Insulin release was expressed as a percentage of the cellular hormone content at the start. Release above basal $(2.5 \mathrm{mmol} / \mathrm{l})$ was induced by $5 \mathrm{mmol} / \mathrm{l}$ glucose and dose-dependently increased by 10 and $20 \mathrm{mmol} / \mathrm{l}$, with further amplification by the addition of glucagon (Fig. 2e).

Table 3 Size and composition of human islet cell implants retrieved from NOD/SCID mice at post-transplant week 5

\begin{tabular}{|c|c|c|c|c|}
\hline & \multicolumn{3}{|l|}{ Free graft } & \multirow{2}{*}{$\begin{array}{l}\text { Normal mouse } \\
\text { pancreas }(n=6)\end{array}$} \\
\hline & Primary non-function $(n=4)$ & Transient function $(n=4)$ & Metabolic correction $(n=4)$ & \\
\hline \multicolumn{5}{|c|}{ Cell mass in implant $(\mu \mathrm{l})$} \\
\hline Beta cells & $0.05 \pm 0.03^{* * *}$ & $0.28 \pm 0.09^{*}$ & $0.54 \pm 0.06$ & $0.85 \pm 0.06^{*}$ \\
\hline Alpha cells & $0.10 \pm 0.05$ & $0.27 \pm 0.05$ & $0.26 \pm 0.04$ & $0.20 \pm 0.01$ \\
\hline Alpha + beta cells & $0.15 \pm 0.07^{* * *}$ & $0.55 \pm 0.14$ & $0.80 \pm 0.04$ & $1.05 \pm 0.07$ \\
\hline Duct cells & $0.12 \pm 0.06$ & $0.09 \pm 0.02$ & $0.10 \pm 0.01$ & NA \\
\hline \multicolumn{5}{|l|}{ Insulin content $(\mu \mathrm{g})$} \\
\hline Implant & $1.0 \pm 0.1^{* * *}$ & $2.7 \pm 0.4$ & $17.9 \pm 2.1$ & NA \\
\hline Pancreas & $1.6 \pm 1.5$ & $0.3 \pm 0.2$ & $0.7 \pm 0.3$ & $30.0 \pm 5.8^{* *}$ \\
\hline
\end{tabular}

Data represent means \pm SEM

Statistical analysis of differences between groups was calculated using an unpaired two-tailed $t$ test and expressed as differences from the subgroup with metabolic correction

${ }^{*} p<0.05, * * p<0.01, * * * p<0.001$

NA, not applicable 
a

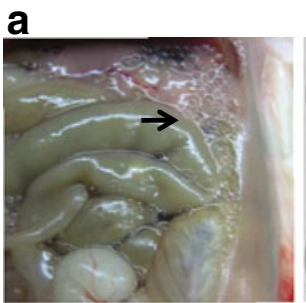

C

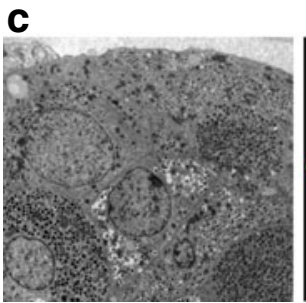

e

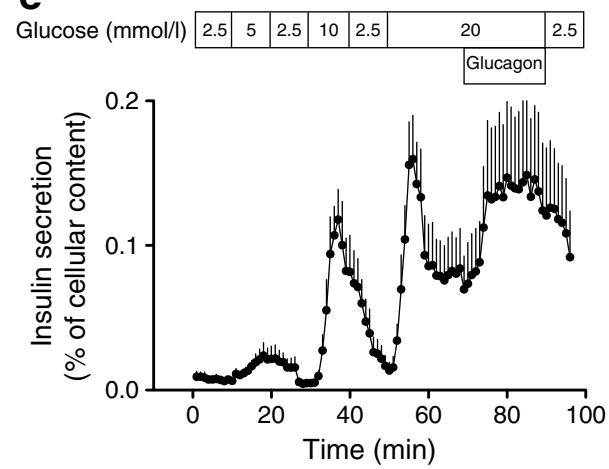

Fig. 2 Analysis of encapsulated human beta cell implant in NOD/ SCID mice at post-transplant week 5. Free-floating capsules (arrow) in the peritoneal cavity (a) were retrieved as single units without fibrosis or cellular overgrowth (b). They contained well-granulated endocrine islet cells (c) that stained positively for insulin (green) and glucagon (red) (d). Their insulin release was examined in perifusion at $10 \mathrm{~min}$ episodes of varying glucose concentration with and without $10 \mathrm{nmol} / 1$ glucagon. The rate of insulin release is expressed as a function of the cellular insulin content before perifusion (e). Data represent means \pm SEM from five independent experiments

Long-term survival and function of alginate-encapsulated human beta cell implants in NOD/SCID mice and in a type 1 diabetic patient Six NOD/SCID mouse recipients of alginate-encapsulated human beta cells grafts were followed for 20-30 weeks. All maintained plasma human C-peptide levels above $0.5 \mathrm{nmol} / 1$ with non-fasting blood glucose $<8.5 \mathrm{mmol} / \mathrm{l}$. When the capsules were retrieved at the end of this study, they were microscopically comparable with those at post-transplant week 5 .

On the basis of these observations, an encapsulated human beta cell preparation was injected into the peritoneal cavity of a type 1 diabetic patient under maintenance immune-suppressive therapy for a prior intraportal beta cell graft. The cellular composition of this preparation was comparable with that used in mice, but the number of implanted beta cells was more than 30 -fold lower when expressed per $\mathrm{kg} \mathrm{BW}\left(2.4 \times 10^{6}\right.$ vs $95 \times 10^{6}$
Table 4 Cellular composition of human islet cell implants at posttransplant week 5 with that of corresponding grafts

\begin{tabular}{|c|c|c|c|c|}
\hline \multirow[t]{2}{*}{ Composition } & \multicolumn{3}{|l|}{ Free graft } & \multirow{2}{*}{$\begin{array}{l}\text { Encapsulated } \\
\text { graft with } \\
\text { metabolic } \\
\text { correction } \\
(n=16)\end{array}$} \\
\hline & $\begin{array}{l}\text { Primary } \\
\text { non-function } \\
(n=4)\end{array}$ & $\begin{array}{l}\text { Transient } \\
\text { function } \\
(n=4)\end{array}$ & $\begin{array}{l}\text { Metabolic } \\
\text { correction } \\
(n=4)\end{array}$ & \\
\hline \multicolumn{5}{|l|}{ Graft } \\
\hline Beta cells $(\%)$ & $19 \pm 1$ & $47 \pm 1$ & $52 \pm 2$ & $42 \pm 4$ \\
\hline Alpha cells $(\%)$ & $4 \pm 1$ & $14 \pm 1$ & $15 \pm 1$ & $12 \pm 1$ \\
\hline Duct cells $(\%)$ & $68 \pm 1$ & $32 \pm 4$ & $32 \pm 3$ & $41 \pm 4$ \\
\hline \multicolumn{5}{|l|}{ Implant } \\
\hline Beta cells $(\%)$ & $18 \pm 4$ & $42 \pm 5$ & $60 \pm 4$ & $54 \pm 5^{* * *}$ \\
\hline Alpha cells (\%) & $36 \pm 1^{* * * *}$ & $45 \pm 4^{* *}$ & $29 \pm 5$ & $18 \pm 2^{* *}$ \\
\hline Duct cells (\%) & $46 \pm 4^{*}$ & $14 \pm 2^{*}$ & $11 \pm 1^{*}$ & $20 \pm 6^{* * *}$ \\
\hline
\end{tabular}

Data represent means \pm SEM

Statistical analysis of differences between percentages in grafts and implants was calculated using a two-tailed paired $t$ test

${ }^{*} p<0.05, * * p<0.01, * * * p<0.001$

beta cells/kg BW). Plasma C-peptide levels increased above pre-transplant levels for 12 weeks (from $<0.07 \mathrm{nmol} / 1$ before transplant to $0.13-0.6 \mathrm{nmol} / 1$ after transplant) but only reached the $0.17 \mathrm{nmol} / \mathrm{l}$ threshold of a functional implant during the first week [23]. During the 3 month follow-up the daily insulin dose and diabetes autoantibody status remained unchanged (insulin autoantibodies $<0.6 \%$, insulinoma-associated antigen 2 antibodies $<0.44 \%$, GAD antibodies $<2.6 \%$, islet cell antibodies $200 \%$ Juvenile Diabetes Research Foundation units) [29]; no HLA class I or class II antibodies were induced.

Upon laparoscopy at post-transplant month 3, no macroscopic abnormalities were observed and no signs of adhesion between abdominal organs. Clusters of capsules were noticed at several sites, including the greater omentum and the pelvic floor (Fig. 3a). They were embedded in vascularised fibrous tissue containing scattered macrophages and giant cells but few lymphocytes and polynuclear cells; their content mainly consisted of debris; the small number with living cell aggregates was located at the surface of the clusters (Fig. 3b).

We also noticed numerous single capsules loosely attached to the peritoneum and easily retrievable by lavage (Fig. 3a). Their surface was free of fibrosis and attached cells; in phase contrast, they appeared similar to those retrieved from immune-incompetent mice. Several contained living cell aggregates which, on electron microscopy, presented intact well-granulated endocrine cells (Fig. 3c). The ultrastructural and immunocytochemical analysis was indicative of endocrine cell enrichment compared with the initial graft (62\% beta and $16 \%$ alpha cells vs $42 \%$ and $15 \%$ at the start) (Fig. 3d). Significantly fewer non-granulated duct cells were counted ( $12 \%$ vs $45 \%$ at the start), possibly 
a

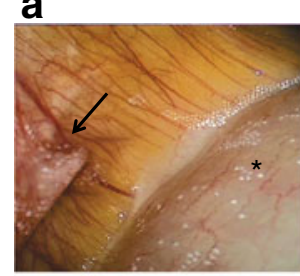

C

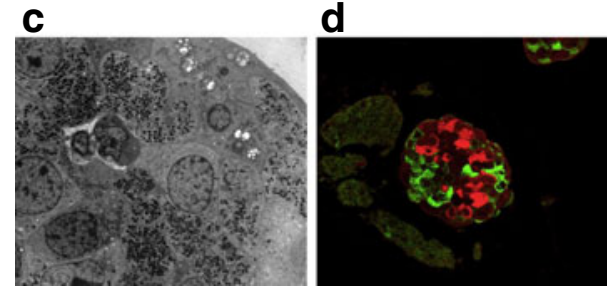

e
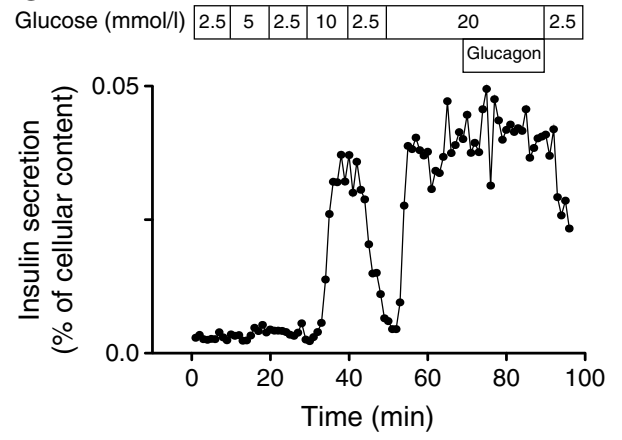

Fig. 3 Analysis of encapsulated human beta cell implant in a type 1 diabetic patient at post-transplant week 12. During laparoscopy, a small fraction of single capsules (arrow) was found free floating in the peritoneal cavity; the largest number was clumped together (asterisk) on the peritoneal wall (a). Aggregated capsules contained mostly cellular debris; some at the periphery presented islet cells (arrow) (b). Free-floating capsules contained well-granulated endocrine islet cells (c) that stained positively for insulin (green) and glucagon (red) (d). Their insulin release was examined in perifusion at 10 min episodes of varying glucose concentrations with and without $10 \mathrm{nmol} / 1$ glucagon. The rate of insulin release is expressed as a function of the cellular insulin content before perifusion (e)

because of their low survival in the capsules ( $44 \%$ dead cells vs $6 \%$ at the start). When free-floating capsules were perifused, a rapid and potent insulin secretory response was induced by $10 \mathrm{mmol} / \mathrm{l}$ glucose. The amplitude was maintained at $20 \mathrm{mmol} / \mathrm{l}$ glucose but not amplified, nor after the addition of glucagon, which is at variance with capsules retrieved from mice (Fig. 3e). Expression of insulin release as a percentage of cellular insulin content at the start indicated that basal release was low and that glucose-stimulated release represented a smaller fraction than in capsules retrieved from mice. Further studies on retrieved beta cells are needed to identify whether this lower discharge is caused by a low percentage of glucoseactivated beta cells and/or by an insufficient stimulussecretion coupling in responsive cells as a result of an inadequate microenvironment.

\section{Discussion}

Immunodeficient rodents can serve as a model to predict, or at least test, the metabolic efficacy of human beta cell grafts used in clinical trials [30-32]. This study investigated the influence of alginate encapsulation on their outcome in diabetic NOD/SCID mice and examined influences of their cellular composition. Encapsulated implants in the peritoneal cavity induced an immediate and sustained correction of blood glucose in all recipients, whereas this was only the case for one-third of free implants under the kidney capsule, with a delay of more than 1 week. Subcapsular implants underwent a substantial beta cell loss particularly in grafts with a larger duct cell mass. This difference has not been previously observed. Our data are difficult to compare with those of other studies given the differences in graft characteristics and implant sites [33, 34]. Outcome can vary with the use of fresh or cultured preparations, with differences in cellular composition and in initial beta cell number and purity [35]. These influences should be identified, as they guide the preparation of clinical grafts and the interpretation of their outcome.

Use of cultured human beta cell grafts allows their characterisation and standardisation in size, viability and cellular composition. Our preparations consist of over $90 \%$ beta, alpha and duct cells. The high percentage of duct cells ( $40 \%$ on average) raises questions about their influence on graft outcome in patients [35]. In rat islet cell grafts, a high proportion of pancreatic non-endocrine cells were found to interfere with their function as intraportal implants [18]. When investigated in vitro, human duct cells exhibited inflammatory and immune properties [36-41]. The cells reacted more vigorously to cytokines than did associated endocrine cells as judged by the expression of MHC class II [36], CD40 [38, 41] or nitric oxide synthase, and by the synthesis and release of other cytokines [37,39]. They were also found to exert a potent procoagulant activity, related to their higher expression of tissue factor [40]. Indirect support also comes from diabetic nude rats in which intraportally injected human islet cell implants caused an inflammatory reactivity that was followed by failure to correct hyperglycaemia [21]. There was less inflammation in omental implants, but sustained metabolic correction was only seen for grafts with a lower percentage of duct cells [21]. The present data in mice also indicate this correlation for free grafts under the kidney capsule. In this model, the failure of grafts with a larger duct cell mass may not only be attributable to a higher inflammatory activity but may also be caused by more severe hypoxia in their compact subcapsular implants. A comparative prospective study in man has not yet been conducted, as it faces the difficulty of preparing human islet cell grafts with low percentages of duct cells. In a retrospective analysis of type 1 diabetic islet 
graft recipients, a weak correlation was seen between the number of duct cells injected and the acute insulin secretory response at post-transplant year 2, but this was not further examined against other variables [42].

Only a subgroup of free graft recipients (4/12) exhibited a metabolic correction, as in other animal studies with human islet cell grafts [43-45]. The effect was not achieved within the first week, probably reflecting the time needed to vascularise implants in an extravascular space [46], and probably not facilitated in compact subcapsular implants. Revascularisation may have been too slow or inadequate in the eight other recipients, leading to necrosis and, hence, undetectable (primary non-function) or metabolically insufficient plasma human C-peptide levels that progressed to negativity (transient function). At post-transplant week 5, these failing implants contained a beta cell mass that was disproportionally low when compared with the corresponding alpha or duct cell mass. This was also the case with respect to the beta cell mass in normalised animals that had received the same number of beta cells at the start. Such beta cell preferential loss might result from their higher susceptibility to hypoxia during impaired or delayed revascularisation. It was highest in the primary non-function subgroup, possibly related to their higher proportion of duct cells and the higher cell mass that had to be implanted in order to inject similar numbers of beta cells. It might also have been caused by the chronic hyperglycaemic state [47], which could also explain the progressive beta cell loss in the transient function subgroup. Beta cells that survived in these diabetic animals were degranulated, which, together with the beta cell loss, reduced the insulin content of the failing implants to $5 \%$ of that in the initial grafts and to $9 \%$ of the values in a normal mouse pancreas. These processes did not occur, or to a much lower extent, in implants of the subgroup with sustained metabolic correction: their beta cell mass and insulin content represented $60 \%$ of the values in the normal mouse pancreas, sufficient to maintain high plasma human C-peptide levels.

Alginate-encapsulated implants in the peritoneal cavity corrected hyperglycaemia immediately, which is indicative of diffusion - from the first post-transplant days - of sufficient insulin from the free-floating capsules. In all recipients, metabolic correction was maintained until the end of the study, irrespective of the percentage of duct cells in the initial grafts. Higher proportions of duct cells thus interfere less with human beta cell functions in this condition where the graft is dispersed and free floating in alginate microcapsules without direct contact with host tissue. The majority of injected capsules were retrieved by peritoneal lavage and were found to be virtually free of fibrosis. They contained up to $80 \%$ viable cells with marked endocrine cell enrichment compared with the initial grafts. This enrichment was also noticed in free implants with metabolic correction and may result from a higher loss of duct cells than beta cells in implants with adequate perfusion at an early stage. The ability to retrieve encapsulated human beta cell implants from the recipients led us to investigate directly their functional properties during the phase where they achieve a sustained metabolic correction. Their perifusion demonstrated rapid, potent and dosedependent insulin responses to glucose, together with a marked amplifying effect of glucagon, which are the hallmarks of physiologically responsive beta cells [48].

On the basis of the observations in mice we conducted a pilot study in a type 1 diabetic patient to assess whether similar properties were identified in her alginate-encapsulated human beta cell implant. Previous studies have reported on the techniques, the safety and the outcome of alginate-encapsulated human $[15,17]$ and porcine [49] islet cell grafts in the peritoneal cavity of diabetic patients. They have documented the feasibility of this type of implantation but not yet its metabolic success. We selected a patient who was on immune suppression for a prior intraportal beta cell implant which had recently lost function. The patient gave her consent for a peritoneal implant under prolonged immune therapy, i.e. until loss of function. This pilot study thus did not assess whether encapsulation provided any immune protection but investigated whether encapsulated implants maintain surviving and functioning beta cells. As in the paper of Tuch et al [17], plasma C-peptide levels were only indicative of graft function during the first post-transplant week. Up to month 3, they remained higher than pre-transplantation levels, always marginally low, but reflecting the presence of functional beta cells within implanted capsules as was demonstrated by analysis of retrieved capsules. These were sampled from a free-floating fraction and found to contain endocrine islet tissue with intact and well-granulated alpha and beta cells. Perifusion showed the presence of glucose-sensitive beta cells, with a low basal release, a potent response to $10 \mathrm{mmol} / \mathrm{l}$ glucose and a sustained release at $20 \mathrm{mmol} / \mathrm{l}$ glucose whether glucagon was present or not. However, in contrast to the study in mice, the majority of capsules were found to be aggregated in large clumps, sticking to the abdominal wall, surrounded by fibrotic tissue and containing mostly debris. An inflammatory reaction to the biomaterial may have initiated aggregation. The persistent hyperglycaemia may have impaired beta cell survival, leading to beta cell loss, as in free implants in mice, and subsequently to aggregation of debris-containing capsules. Aggregation of capsules may also have occurred by their clustering at adhesion or sedimentation points in the abdominal cavity, such as the pelvic floor, leading to hypoxia and debris. It is a likely cause of their metabolic failure in man, rather than the inability of human islet endocrine cells to survive and function in alginate capsules. Methods that avoid aggregation should therefore improve metabolic outcome. Their development needs to combine expertise in biomaterials and beta cell biology with the availability of preclinical models for translation to clinical trials. 
Acknowledgements The authors thank R. Calafiore and G. Basta (University of Perugia, Italy) for helping with encapsulation in preceding studies; K. Suenens, S. Darwich, S. Devos, M. Bomans, M. Berghmans, L. Heylen and N. van Slycke for their skilful technical support and secretarial assistance; and S. Uyttenhove for her excellent administrative management. They are grateful to the beta cell bank at Brussels Free University (Brussels, Belgium) and the Eurotransplant International Foundation (Leiden, the Netherlands) for providing human islet cell preparations.

Funding This study was supported by grants from the JDRF (centre grant 4-2005-1327), the Research Foundation Flanders (G.0801.10), the 6th and 7th Framework Program of the European Commission (numbers 512145 and 241883), and the Agency for Innovation by Science and Technology in Flanders (IWT-TBM7 090884). D. Jacobs-Tulleneers-Thevissen and M. Chintinne were PhD fellows of the Research Foundation Flanders.

Duality of interest The authors declare that there is no duality of interest associated with this manuscript.

Contribution statement Substantial contributions to the conception and design of the study were made by LS and BLS (encapsulation) and by GD, PG and BK (clinical trial). ZL, MC, PG, BK, FG, DJTT and DP contributed to the acquisition of data. MC, DJTT and DP contributed to the analysis and interpretation of data. DJTT and DP drafted the article. All authors revised the article critically for important intellectual content and gave their final approval of the version to be published.

\section{References}

1. Ryan EA, Paty BW, Senior PA et al (2005) Five-year follow-up after clinical islet transplantation. Diabetes 54:2060-2069

2. Moberg L, Johansson H, Lukinius A et al (2002) Production of tissue factor by pancreatic islet cells as a trigger of detrimental thrombotic reactions in clinical islet transplantation. Lancet 360:2039-2045

3. Roep BO, Stobbe I, Duinkerken G et al (1999) Auto- and alloimmune reactivity to human islet allografts transplanted into type 1 diabetic patients. Diabetes 48:484-490

4. Hilbrands R, Huurman VAL, Gillard P et al (2009) Differences in baseline lymphocyte counts and autoreactivity are associated with differences in outcome of islet cell transplantation in type 1 diabetic patients. Diabetes 58:2267-2276

5. de Vos P, Hamel AF, Tatarkiewicz K (2002) Considerations for successful transplantation of encapsulated pancreatic islets. Diabetologia 45:159-173

6. O'Sullivan ES, Vegas A, Anderson DG, Weir GC (2011) Islets transplanted in immunoisolation devices: a review of the progress and the challenges that remain. Endocr Rev 32:827-844

7. Lim F, Sun AM (1980) Microencapsulated islets as bioartificial endocrine pancreas. Science 210:908-910

8. de Vos P, Bucko M, Gemeiner P et al (2009) Multiscale requirements for bioencapsulation in medicine and biotechnology. Biomaterials 30:2559-2570

9. Qi M, Strand BL, Mørch Y et al (2008) Encapsulation of human islets in novel inhomogeneous alginate- $\mathrm{Ca} 2+/ \mathrm{Ba} 2+$ microbeads: in vitro and in vivo function. Artif Cells Blood Substit Immobil Biotechnol 36:403-420
10. Mazaheri R, Atkison P, Stiller C, Dupré J, Vose J, O'Shea G (1991) Transplantation of encapsulated allogeneic islets into diabetic BB/W rats. Effects of immunosuppression. Transplantation 51:750-754

11. Duvivier-Kali VF, Omer A, Parent RJ, O'Neil JJ, Weir GC (2001) Complete protection of islets against allorejection and autoimmunity by a simple barium-alginate membrane. Diabetes 50:16981705

12. Omer A, Duvivier-Kali V, Fernandes J, Tchipashvili V, Colton CK, Weir GC (2005) Long-term normoglycemia in rats receiving transplants with encapsulated islets. Transplantation 79:52-58

13. Soon-Shiong P, Feldman E, Nelson R et al (1993) Long-term reversal of diabetes by the injection of immunoprotected islets. Proc Natl Acad Sci USA 90:5843-5847

14. Wang T, Adcock J, Kühtreiber W et al (2008) Successful allotransplantation of encapsulated islets in pancreatectomized canines for diabetic management without the use of immunosuppression. Transplantation 85:331-337

15. Basta G, Montanucci P, Luca G et al (2011) Long-term metabolic and immunological follow-up of nonimmunosuppressed patients with type 1 diabetes treated with microencapsulated islet allografts: four cases. Diabetes Care 34:2406-2409

16. Calafiore R, Basta G, Luca G et al (2006) Microencapsulated pancreatic islet allografts into nonimmunosuppressed patients with type 1 diabetes: first two cases. Diabetes Care 29:137-138

17. Tuch BE, Keogh GW, Williams LJ et al (2009) Safety and viability of microencapsulated human islets transplanted into diabetic humans. Diabetes Care 32:1887-1889

18. Keymeulen B, Korbutt G, de Paepe M, Gorus F, Klöppel G, Pipeleers DG (1996) Long-term metabolic control by rat islet grafts depends on the composition of the implant. Diabetes 45:1814-1821

19. Keymeulen B, Ling Z, Gorus FK et al (1998) Implantation of standardized beta-cell grafts in a liver segment of IDDM patients: graft and recipients' characteristics in two cases of insulinindependence under maintenance immunosuppression for prior kidney graft. Diabetologia 41:452-459

20. Bogdani M, Lefèbvre V, Buelens $\mathrm{N}$ et al (2003) Formation of insulin-positive cells in implants of human pancreatic duct cell preparations from young donors. Diabetologia 46:830-838

21. Jacobs-Tulleneers-Thevissen D, Bartholomeus K, Suenens K et al (2010) Human islet cell implants in a nude rat model of diabetes survive better in omentum than in liver with a positive influence of beta cell number and purity. Diabetologia 53:1690-1699

22. Truyen I, de Pauw P, Jørgensen PN et al (2005) Proinsulin levels and the proinsulin:C-peptide ratio complement autoantibody measurement for predicting type 1 diabetes. Diabetologia 48:2322-2329

23. Keymeulen B, Gillard P, Mathieu C et al (2006) Correlation between beta cell mass and glycemic control in type 1 diabetic recipients of islet cell graft. Proc Natl Acad Sci USA 103:17444-17449

24. Pipeleers DG, Pipeleers-Marichal M, Vanbrabandt B, Duys S (1991) Transplantation of purified islet cells in diabetic rats. II. Immunogenicity of allografted islet beta-cells. Diabetes 40:920-930

25. Chintinne M, Stangé G, Denys B et al (2010) Contribution of postnatally formed small beta cell aggregates to functional beta cell mass in adult rat pancreas. Diabetologia 53:2380-2388

26. Pipeleers DG, Pipeleers-Marichal M, Hannaert JC et al (1991) Transplantation of purified islet cells in diabetic rats. I. Standardization of islet cell grafts. Diabetes 40:908-919

27. Pipeleers D, in't Veld PI, Maes E, van de Winkel M (1982) Glucose-induced insulin release depends on functional cooperation between islet cells. Proc Natl Acad Sci USA 79:7322-7325

28. Van Schravendijk CF, Kiekens R, Pipeleers DG (1992) Pancreatic beta cell heterogeneity in glucose-induced insulin secretion. J Biol Chem 267:21344-21348

29. Vermeulen I, Weets I, Costa O et al (2011) An important minority of prediabetic first-degree relatives of type 1 diabetic patients 
derives from seroconversion to persistent autoantibody positivity after 10 years of age. Diabetologia 55:413-420

30. Ricordi C, Scharp DW, Lacy PE (1988) Reversal of diabetes in nude mice after transplantation of fresh and 7-day-cultured (24 degrees C) human pancreatic islets. Transplantation 45:994-996

31. Ichii H, Inverardi L, Pileggi A et al (2005) A novel method for the assessment of cellular composition and beta-cell viability in human islet preparations. Am J Transplant 5:1635-1645

32. Caiazzo R, Gmyr V, Kremer B et al (2008) Quantitative in vivo islet potency assay in normoglycemic nude mice correlates with primary graft function after clinical transplantation. Transplantation 86:360-363

33. Schneider S, Feilen PJ, Brunnenmeier F et al (2005) Long-term graft function of adult rat and human islets encapsulated in novel alginate-based microcapsules after transplantation in immunocompetent diabetic mice. Diabetes 54:687-693

34. Vaithilingam V, Barbaro B, Oberholzer J, Tuch BE (2011) Functional capacity of human islets after long-distance shipment and encapsulation. Pancreas 40:247-252

35. Pipeleers D, Keymeulen B, Chatenoud L et al (2002) A view on beta cell transplantation in diabetes. Ann N Y Acad Sci 958:69-76

36. Pavlovic D, van de Winkel M, van der Auwera B et al (1997) Effect of interferon-gamma and glucose on major histocompatibility complex class I and class II expression by pancreatic beta- and non-beta-cells. J Clin Endocrinol Metab 82:2329-2336

37. Pavlovic D, Chen MC, Bouwens L, Eizirik DL, Pipeleers D (1999) Contribution of ductal cells to cytokine responses by human pancreatic islets. Diabetes 48:29-33

38. Vosters O, Beuneu C, Nagy N et al (2004) CD40 expression on human pancreatic duct cells: role in nuclear factor-kappa B activation and production of pro-inflammatory cytokines. Diabetologia 47:660 668

39. Movahedi B, van de Casteele M, Caluwé N et al (2004) Human pancreatic duct cells can produce tumour necrosis factor-alpha that damages neighbouring beta cells and activates dendritic cells. Diabetologia 47:998-1008

40. Beuneu C, Vosters O, Movahedi B et al (2004) Human pancreatic duct cells exert tissue factor-dependent procoagulant activity: relevance to islet transplantation. Diabetes 53:1407-1411

41. Klein D, Timoneri F, Ichii H, Ricordi C, Pastori RL (2008) CD40 activation in human pancreatic islets and ductal cells. Diabetologia 51:1853-1861

42. Street CN, Lakey JRT, Shapiro AMJ et al (2004) Islet graft assessment in the Edmonton Protocol: implications for predicting longterm clinical outcome. Diabetes 53:3107-3114

43. Ihm SH, Matsumoto I, Sawada T et al (2006) Effect of donor age on function of isolated human islets. Diabetes 55:1361-1368

44. Papas KK, Colton CK, Nelson RA et al (2007) Human islet oxygen consumption rate and DNA measurements predict diabetes reversal in nude mice. Am J Transplant 7:707-713

45. Davalli AM, Perego L, Bertuzzi F et al (2008) Disproportionate hyperproinsulinemia, beta-cell restricted prohormone convertase 2 deficiency, and cell cycle inhibitors expression by human islets transplanted into athymic nude mice: insights into nonimmunemediated mechanisms of delayed islet graft failure. Cell Transplant 17:1323-1336

46. Jansson L, Carlsson P-O (2002) Graft vascular function after transplantation of pancreatic islets. Diabetologia 45:749-763

47. Zini E, Osto M, Franchini M et al (2009) Hyperglycaemia but not hyperlipidaemia causes beta cell dysfunction and beta cell loss in the domestic cat. Diabetologia 52:336-346

48. Pipeleers DG, Schuit FC, in't Veld PA (1985) Interplay of nutrients and hormones in the regulation of insulin release. Endocrinology 117:824-833

49. Elliott RB, Escobar L, Tan PLJ, Muzina M, Zwain S, Buchanan C (2007) Live encapsulated porcine islets from a type 1 diabetic patient $9.5 \mathrm{yr}$ after xenotransplantation. Xenotransplantation $14: 157-161$ 